\title{
"The effect of applying COSO-ERM model on reducing fraudulent financial reporting of commercial banks in Jordan"
}

\begin{tabular}{|c|c|}
\hline AUTHORS & $\begin{array}{l}\text { Abdul Aziz A. Abdul Rahman } \\
\text { Othman Hel Ajmi Al-Dhaimesh }\end{array}$ \\
\hline ARTICLE INFO & $\begin{array}{l}\text { Abdul Aziz A. Abdul Rahman and Othman Hel Ajmi Al-Dhaimesh (2018). The } \\
\text { effect of applying COSO-ERM model on reducing fraudulent financial reporting of } \\
\text { commercial banks in Jordan. Banks and Bank Systems, 13(2), 107-115. } \\
\text { doi:10.21511/bbs.13(2).2018.09 }\end{array}$ \\
\hline DOI & http://dx.doi.org/10.21511/bbs.13(2).2018.09 \\
\hline RELEASED ON & Monday, 25 June 2018 \\
\hline RECEIVED ON & Tuesday, 22 May 2018 \\
\hline ACCEPTED ON & Friday, 15 June 2018 \\
\hline LICENSE & $\begin{array}{l}(c) \text { EY-NG } \\
\text { This work is licensed under a Creative Commons Attribution-NonCommercial } 4.0 \\
\text { International License }\end{array}$ \\
\hline JOURNAL & "Banks and Bank Systems" \\
\hline ISSN PRINT & $1816-7403$ \\
\hline ISSN ONLINE & $1991-7074$ \\
\hline PUBLISHER & LLC "Consulting Publishing Company "Business Perspectives" \\
\hline FOUNDER & LLC "Consulting Publishing Company "Business Perspectives" \\
\hline
\end{tabular}

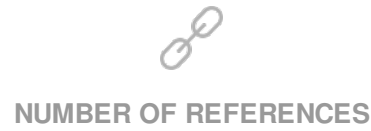

16

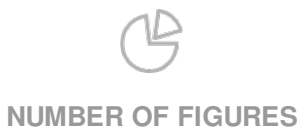

0
NUMBER OF TABLES

8

(C) The author(s) 2022. This publication is an open access article. 


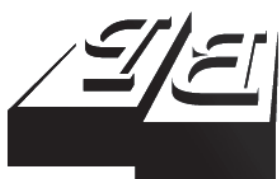

BUSINESS PERSPECTIVES

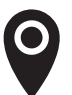

LLC “CPC "Business Perspectives” Hryhorii Skovoroda lane, 10, Sumy, 40022, Ukraine

www.businessperspectives.org

Received on: $22^{\text {nd }}$ of May, 2018 Accepted on: $15^{\text {th }}$ of June, 2018

(C) Abdul Aziz A. Abdul Rahman, Othman Hel Ajmi Al-Dhaimesh, 2018

Abdul Aziz A. Abdul Rahman, Dr., Assistant Professor, Department of Finance and Accounting, College of Business Administration, Kingdom University, Bahrain.

Othman Hel Ajmi Al-Dhaimesh, Dr., Assistant Professor, Department of Finance and Accounting, College of Business Administration, Kingdom University, Bahrain.

\section{(ㄷ)(1) $(8)$}

This is an Open Access article, distributed under the terms of the Creative Commons Attribution-NonCommercial 4.0 International license, which permits re-use, distribution, and reproduction, provided the materials aren't used for commercial purposes and the original work is properly cited.

\section{THE EFFECT OF APPLYING COSO-ERM MODEL ON REDUCING FRAUDULENT FINANCIAL REPORTING OF COMMERCIAL BANKS IN JORDAN}

\section{Abstract}

This study aims to test the effect of applying the model of the Committee Sponsoring Organizations for enterprise risk management (COSO-ERM) on reducing fraudulent financial reporting in commercial banks operating in Jordan. Furthermore, the study identifies the role of each board of directors, audit committee, executive management, human resource management, and internal audit as one of the corporate governance mechanisms in enhancing the effectiveness of internal control systems.

The study revealed an impact of applying the Committee of Sponsoring Organizations model for enterprise risk management (COSO-ERM) on preventing fraudulent financial reporting, where it reached influence around $77.8 \%$ on the dependent variable (fraudulent financial reporting). The study also found that each of internal control, event identification, risk assessment and response, and control activities variables affects dependent variable (fraudulent financial reporting) in commercial banks operating in Jordan.

\section{Keywords}

Internal Control System, Committee of Sponsoring Organization (COSO-ERM), Fraudulent Financial Reporting

JEL Classification H83, G21, E58, Q52

\section{INTRODUCTION}

The importance of the internal control systems has recently become increasingly sensitive to the global financial scandals that have plagued the world economy due to widespread fraud, financial and administrative corruption and unethical practices, which led to collapse of major international business organizations. As a result, in 1985, the National Committee for Dealing with Fraudulent Financial Reporting (Treadway Commission) was established, consisting of five major professional associations in America, which are American Accounting Association (AAA), American Institute of Certified Public Accountants (AICPA), Institute of Internal Auditors (IIA), Institute of Management Accountants (IMA), and Institute of Financial Managers (FEI). The Committee studied the financial information reporting systems during the period 1985-1987. In October 1987, the Committee issued a report entitled "Report of the National Committee for Preparation of Financial Reporting" which led to establishment of the Committee of Sponsoring Organizations (COSO), resulting in increased attention to internal control systems to ensure that the objectives of economic units are met by international professional sponsoring organizations, especially the International Federation of Accountants (IFAC). 
In 1992, the Committee of Sponsoring Organizations issued COSO-Cube model to provide guidance and strengthen internal control systems in organizations. This model was widely accepted by most organizations around the world. Nine years after the model was issued, the Committee of Sponsoring Organizations began to develop a mechanism for effective identification, assessment and management of risk, so that organizations could improve risk management. The result was to develop the COSOERM model which focuses on risk rather than just control.

\section{PROBLEM STATEMENT}

The financial scandals, which have recently led to collapse of major business organizations, reveal the weakness of the internal control and risk management systems for many reasons, including the absence of the effective role of the board of directors and the audit committees in supervising on management activities and internal control systems, lack of good organizational structure that ensure that the management sub-unit operates independently, weak regulatory activities and policies, overlapping of powers, lack of clear plans and objectives, and poor accountability and continuous monitoring of internal control systems by stakeholders are the reasons for weakness of internal control and risk assessment systems (IFAC, 2012).

Accordingly, organizations are required to build effective internal control systems capable of preventing fraud and corruption, as well as to obtain reasonable assurance that the reliable financial statement, efficient and effective operations, and compliance with policies, laws and regulations have been achieved.

Thus, the problem statement of this study can be summarized by the following key question: Does applying COSO-ERM model prevent fraudulent financial reporting in commercial banks operating in Jordan?

\section{IMPORTANCE OF THE STUDY}

The importance of this study arises through the adoption by many stakeholders in making their investment and credit decisions on the quality of the outputs of internal control systems, which are reflected in the accuracy and reliability of financial and non-financial reports. The external auditor also depends primarily on the strength of the internal control systems in identifying control risks. Thus, internal control systems play an important role in enhancing the ability of the board of directors and executive management to achieve objectives of banks, protect the rights of shareholders and owners, and reduce fraudulent financial reporting that do not reflect the correct financial situation in business organizations, especially in the banking sector.

\section{OBJECTIVE OF THE STUDY}

This study aims to examine the impact of applying COSO-ERM model on enhancing the effectiveness of internal control systems in reducing fraudulent financial reporting, to assess the effectiveness of the internal control systems applied in banks by verifying the extent of applying the COSO-ERM model criteria, and to suggest appropriate recommendations.

\section{THE HYPOTHESES OF THE STUDY}

The study hypotheses were built depending on the COSO-ERM framework issued by the Committee of Sponsoring Organizations, in addition to the international audit standards No. 240 related to fraud issued by IFAC. Based on the above, the main study hypotheses were made:

H0: Applying COSO-ERM model does not affect reducing fraudulent financial reporting in commercial banks operating in Jordan.

This hypothesis is divided into the following sub-hypotheses:

H01: Internal environment does not affect reducing fraudulent financial reporting. 
H02: Objective setting does not affect reducing fraudulent financial reporting.

H03: Event identification does not affect reducing fraudulent financial reporting.

H04: Risk assessment and response do not affect reducing fraudulent financial reporting.

H05: Control activities do not affect reducing fraudulent financial reporting.

H06: Information and communication system does not affect reducing fraudulent financial reporting.

H07: Monitoring does not affect reducing fraudulent financial reporting.

\section{LITERATURE REVIEW}

Most studies related to internal control systems according to COSO, ERM and fraud have been surveyed. The study by Adebiyi Ifeoluwa Mary (2017) aims at showing the impact of effective internal control on the management of mother and child hospital Akure in Ondo State. The result showed that internal control had a significant impact on the management of government institutions. The researcher also concluded that adequate internal control and strict adherence to management policies should be maintained to ensure that the objectives of the quasi-governmental organizations were met.

New study (Kehinde Adekunle Adetiloye et al., 2016) aims to show the fraud prevention and internal control in the Nigerian banking system. The results showed that internal control itself was effective against fraud, but not all employees were committed to it, while secondary data largely supported but was more reflective of the initial data, and staff qualifications and technology are important in various dependent variables. It is also evident from the regression that technology-based fraud is important.

Joseph Oguda Ndege et al. (2015) found a positive relationship between the effectiveness of internal control systems and detection and prevention of fraud at a significant level in the treasury accounts section of the Kenyan banks. The study also showed that the variable control activities ranked first in the prevention and detection of fraud, followed by the risk assessment variable, they are followed by the monitoring variable and the regulatory environment variable.

Ayagre et al. (2014) assessed the control environment and monitoring activities as a key element of internal control systems in accordance with COSO-Cube model. The Guinean banks have effective internal control systems and indicate a strong control for the sub-components of the control environment, such as the administration's support of moral values, integrity and commitment to efficiency by employees, participation of all those involved in institutional control and decision-making process, responsibilities and powers, and human resources policies. The results also indicate that there are control systems in Guinean banks in accordance with the model mentioned.

Ani Odunayo Boyepe (2014) pointed at a possibility of preparing fraudulent financial reporting by Nigerian companies listed on the stock markets and showed a strong correlation between the company's size and the preparation of fraudulent financial reporting and a strong correlation between fraudulent financial reporting and the weakness of internal control systems and audit committees making them ineffective in mitigating the risk of fraudulent financial reporting.

To highlight the role of the audit committees as one of the corporate governance mechanisms in preventing fraud, Mohammed and Dahdouh (2013) determined the role of audit committees in preventing fraud in Syrian corporate companies by focusing on control of establishing audit committees. The study showed the audit committees had an effect on preventing fraud Syrian corporate companies.

The study by Abiola and Oyewole (2013) indicated that the internal control system at the Bank of Melat is able to reduce fraud and errors. Also, there is a relationship between the weakness of elements of internal control systems and increase in fraud and errors. Similar study (Salehi et al., 2013) 
indicated a strong correlation between training employees and detecting fraud, which means that advanced training for employees will increase the chance of detecting fraud, and also a strong relationship between the internal control system and detecting fraud, which means that having efficient internal control systems will increase the chance of detecting fraud.

Ghosh (2013) pointed out that there is an impact of the internal control system, programs of preventing fraud, and risk management on reducing fraud risk. Rameli (2013) stated that high-volume, high-profitability and complex companies prefer adopting an ERM framework to manage their internal and external risks more than small companies. Furthermore, adopting ERM framework significantly affects reducing fraudulent financial reporting.

Algire (2013) tested the impact of the five components of internal control according to COSOCube to assess the risk of internal control in companies listed on the stock exchange of Damascus. The study found an effect of the five internal control components on assessing the risk of internal control in the sample companies. The study also revealed an effect of control environment on reducing internal control risks, including fraudulent financial reporting. The control activities variable also affected assessing internal control risk. Finally, the follow-up variable affected assessing internal control risk in the surveyed companies.

The study by Al-Azmi (2012) aimed to determine the role of boards of directors in applying internal control standards under COSOCube and its effects on achieving objectives in Kuwaiti industrial companies. The study showed a relationship between applying internal control standards including management's understanding of objectives of internal control, the integration of internal control components or parts, the effectiveness of each part of the internal control structure, the efficiency of internal audit management, levels of using information technology and achieving the objectives of financial reports, compliance objectives, and operational objectives in Kuwaiti industrial companies.
Ahmad and Norhashim (2008) point at a strong correlation between elements of control environment and attitudes of employees towards making frauds in Malaysian companies and also a strong correlation between implementing an effective internal control system, existence of an internal audit department, clear distribution of functions and powers, training and development of employees capabilities, monitoring the internal control system, and existence of a written ethical code and the attitudes of employees towards frauds.

\section{METHODOLOGY OF THE STUDY}

This study depends on the analytical descriptive approach, which tries to describe a phenomenon, to reach the causes of this phenomenon and the factors that control it, and draw conclusions for its generalization. The theoretical literature and the previous studies related to the internal control system and fraud have been reviewed. The data were analyzed and compared by converting non-quantitative variables into measurable quantitative variables, in order to use them in testing hypotheses and show the results and recommendations of the study, thus allowing for a scientific knowledge of this effect by identifying the respondents and data that can be analyzed.

\subsection{Study sample and population}

The study society consists of all banks operating in Jordan. The sample of the study includes 21 commercial banks operating in Jordan. The target individuals include the chairmen and members of the boards of directors, general managers, financial managers, directors and the staff of the Internal Audit Department, and the directors of Information Systems Departments. A total of 210 questionnaires were distributed by 10 questionnaires per bank. 160 questionnaires were received. After calculation, 12 of them were excluded due to incomplete information and 148 questionnaires were adopted.

\subsection{Statistical methods}

The study employs beta coefficient to test the effect of each independent variable on the dependent 
variable, and $R^{2}$ to test the effect of the independent variables together on the dependent variable, by adopting the Multiple Linear Regression.

\section{RESULTS}

\subsection{Testing the main hypothesis of the study $(\mathrm{Ho})$}

The hypothesis states that "Applying COSO-ERM model does not affect on reducing fraudulent financial reporting" in commercial banks operating in Jordan".

To test this hypothesis, the researcher used Multiple Linear Regression analysis using the Stepwise method to identify the effect of independent variables on the value of the dependent variable. Table 1 illustrates the results of testing this hypothesis.

Table 1 shows that the value of the relationship between COSO-ERM model and the dependent variable (fraudulent financial reporting) in commercial banks operating in Jordan is 0.882 . This relation is statistically significant, and the test of $F$ gives 99.31 at the level of significance by 0.000 and since the value of the level of significance is less than 0.05 , this means that this relationship is statistically accepted.

Table 1 also shows five independent variables whose effect has been accepted statistically. This means that there is a linear importance of these variables in reducing fraudulent financial reporting in commercial banks operating in Jordan. While two variables were excluded (information and communication system and monitoring). The values of t-test significance level ( 0.180 and 0.320 , respectively) are statistically insignificant.

The value of the coefficient $\beta$ shows the degree of the effect of the independent variable on the dependent variable, where the value of the effect is 0.241 for internal environment variable, 0.233 for identifying objectives variable, 0.230 for risk assessment and response variable, 0.228 for control activities variable, and 0.162 for setting objectives variable. The greatest value of the effect is internal environment variable. This reflects an effective role for the Board of Directors and its committees, such as the audit committees in controlling the process of financial reporting.

The value of $R^{2}$ indicates that the independent variables with their acceptable effects explain $77.8 \%$ of the change in the dependent variable (fraudulent financial reporting). The results are consistent with the study by Ahmad and Norhashim (2008), which found a relationship between an effective internal control system and reducing the risk of fraudulent financial reporting.

As a result, the researchers reject null hypothesis and accept the alternative hypothesis, which states: "Applying COSO-ERM model affects reducing fraudulent financial reporting in commercial banks operating in Jordan".

Table 1. Results of a multiple linear regression analysis to test the main hypothesis $\left(H_{0}\right)$

\begin{tabular}{|c|c|c|c|c|c|c|c|c|c|c|}
\hline \multicolumn{2}{|c|}{ Independent variables } & $\mathbf{R}$ & $\mathbf{R} 2$ & $\mathbf{F}$ & Sig. $f$ & Sig. $t$ & $\mathbf{t}$ & $\begin{array}{c}\beta \text { non- } \\
\text { normative }\end{array}$ & A & D.W \\
\hline \multirow{5}{*}{ Accepted } & $\begin{array}{l}\text { Internal } \\
\text { environment }\end{array}$ & \multirow{5}{*}{0.882} & \multirow{5}{*}{0.778} & \multirow{5}{*}{99.31} & \multirow{5}{*}{0.000} & 0.000 & 4.281 & 0.241 & \multirow{7}{*}{-0.342} & \multirow{5}{*}{2.073} \\
\hline & $\begin{array}{l}\text { Event } \\
\text { identification }\end{array}$ & & & & & 0.000 & 7.473 & 0.233 & & \\
\hline & $\begin{array}{l}\text { Risk assessment } \\
\text { and response }\end{array}$ & & & & & 0.000 & 7.274 & 0.230 & & \\
\hline & Control activities & & & & & 0.000 & 6.495 & 0.228 & & \\
\hline & Objective setting & & & & & 0.000 & 9.409 & 0.162 & & \\
\hline \multirow[b]{2}{*}{ Rejected } & Monitoring & & & & & 0.320 & 0.998 & 0.042 & & \\
\hline & $\begin{array}{l}\text { Information and } \\
\text { communication }\end{array}$ & & & & & 0.180 & -1.346 & -0.057 & & \\
\hline
\end{tabular}

Note: Independent variables were arranged according to their degree of influence on the dependent variable (descending order). 


\subsection{Testing sub-hypotheses arising from the main hypothesis}

\subsubsection{Testing the first hypothesis (Ho1) coming from the main hypothesis, which states: "Internal environment does not affect reducing fraudulent financial reporting".}

Table 2 illustrates results of the first sub-hypthesis.

Table 2. Results of a simple linear regression analysis to test the first sub-hypothesis ( $\mathrm{HO1}$ )

\begin{tabular}{c|c:c:c|c}
\hline $\begin{array}{c}\text { Independent } \\
\text { variable }\end{array}$ & $\boldsymbol{\beta}$ & $\mathbf{T}$ & Sig. $\mathbf{t}$ & Decision \\
\hline Internal environment & 0.241 & 4.281 & 0.000 & Reject \\
\hline
\end{tabular}

The value of the coefficient $\beta$ shows the effect of the independent variable (internal environment) on the dependent variable (fraudulent financial reporting), where the effect's value is 0.241 . The value of $T$ test shows the linear significance of the independent variable in the linear regression model, where the value of $T$ is 0.000 , which is less than 0.05 . This means that there is a linear importance for internal environment variable in reducing fraudulent financial reporting in commercial banks operating in Jordan.

As a result, the researchers reject null hypothesis and accept the alternative hypothesis, which states: "Internal environment affects reducing fraudulent financial reporting".

\subsubsection{Testing the second hypothesis ( $\mathrm{Ho2}$ ) coming from the main hypothesis, which states: "Objective setting does not affect reducing fraudulent financial reporting".}

Table3illustrates results of the second sub-hypothesis.

Table 3. Results of a simple linear regression analysis to test the second sub-hypothesis (HO2)

\begin{tabular}{c|c|c|c|c}
\hline $\begin{array}{c}\text { Independent } \\
\text { variable }\end{array}$ & $\boldsymbol{\beta}$ & $\mathbf{T}$ & Sig. t & Decision \\
\hline Objectives setting & 0.126 & 9.409 & 0.000 & Reject \\
\hline
\end{tabular}

The value of the coefficient $\beta$ shows the effect of the independent variable (objectives setting) on the dependent variable (fraudulent financial reporting), where the effect's value is 0.126 . The value of $T$ test shows the linear significance of the independent variable in the linear regression model, where the value of $T$ is 0.000 , which is less than 0.05 . This means that there is a linear importance for setting objectives variable in reducing fraudulent financial reporting in commercial banks operating in Jordan.

As a result, the researchers reject null hypothesis and accept the alternative hypothesis which states: "Objective setting affects reducing fraudulent financial reporting".

\subsubsection{Testing the third hypothesis ( $\mathrm{H}_{03}$ ) coming from the main hypothesis, which states: "Events identification does not affect reducing fraudulent financial reporting".}

Table 4 shows the results of Multiple Linear Regression to measure the effect of Identifying events variable in reducing fraudulent financial reporting.

Table 4. Results of a simple linear regression analysis to test the third sub-hypothesis ( $\mathrm{HO})$

\begin{tabular}{l|c|c|c|c}
\hline $\begin{array}{c}\text { Independent } \\
\text { variable }\end{array}$ & $\boldsymbol{\beta}$ & $\mathbf{T}$ & Sig. $\mathbf{t}$ & Decision \\
\hline $\begin{array}{l}\text { Events } \\
\text { identification }\end{array}$ & 0.233 & 7.473 & 0.000 & Reject \\
\hline
\end{tabular}

The value of the coefficient $\beta$ shows the effect of the independent variable (events identification) on the dependent variable (fraudulent financial reporting), where the effect's value is 0.233 . The value of $T$ test shows the linear significance of the independent variable in the linear regression model, where the value of $T$ is 0.000 , which is less than 0.05 . This means that there is a linear importance for identifying events variable in reducing fraudulent financial reporting in commercial banks operating in Jordan.

As a result, the researchers reject zero study hypothesis and accept the alternative hypothesis, which states: "Events identification affects reducing fraudulent financial reporting".

\subsubsection{Testing the fourth hypothesis (Ho4) coming from the main hypothesis, which states: "Risk assessment and response do not affect reducing fraudulent financial reporting".}

Table 5 shows the results of Multiple Linear Regression to measure the effect of risk assessment and response variable on reducing fraudulent financial reporting. 
Table 5. Results of a simple linear regression analysis to test the fourth sub-hypothesis ( $\mathrm{HO4})$

\begin{tabular}{l|c|c|c|c}
\hline $\begin{array}{c}\text { Independent } \\
\text { variable }\end{array}$ & $\boldsymbol{\beta}$ & $\mathbf{T}$ & Sig. $\mathbf{t}$ & Decision \\
\hline $\begin{array}{l}\text { Risk assessment } \\
\text { and response }\end{array}$ & 0.230 & 7.274 & 0.000 & Reject \\
\hline
\end{tabular}

The value of the coefficient $\beta$ shows the effect of the independent variable (risk assessment and response) on the dependent variable (fraudulent financial reporting), where the effect's value is 0.230 . The value of $T$ test shows the linear significance of the independent variable in the linear regression model, where the value of $T$ is 0.000 , which is less than 0.05 . This means that there is a linear importance for risk assessment and response variable in reducing fraudulent financial reporting in commercial banks operating in Jordan.

As a result, the researchers reject zero study hypothesis and accept the alternative hypothesis, which states: "Risk assessment and response affect reducing fraudulent financial reporting".

\subsubsection{Testing the fifth hypothesis (H05) coming from the main hypothesis, which states: "Control activities do not affect reducing fraudulent financial reporting".}

Table 6 shows the results of Multiple Linear Regression to measure the effect of control activities variable on reducing fraudulent financial reporting.

Table 6. Results of a simple linear regression analysis to test the fifth sub-hypothesis (HO5)

\begin{tabular}{l|c|c|c|c}
\hline $\begin{array}{c}\text { Independent } \\
\text { variable }\end{array}$ & $\boldsymbol{\beta}$ & $\mathbf{T}$ & Sig. t & Decision \\
\hline $\begin{array}{l}\text { Control } \\
\text { activities }\end{array}$ & 0.228 & 6.495 & 0.000 & Reject \\
\hline
\end{tabular}

The value of the coefficient $\beta$ shows the effect of the independent variable (control activities) on the dependent variable (fraudulent financial reporting), where the effect's value is 0.228 . The value of $T$ test shows the linear significance of the independent variable in the linear regression model, where the value of $T$ is 0.000 , which is less than 0.05 . This means that there is a linear importance for control activities variable in reducing fraudulent financial reporting in commercial banks operating in Jordan.
As a result, the researchers reject zero study hypothesis and accept the alternative hypothesis, which states: "Control activities affects reducing fraudulent financial reporting".

\subsubsection{Testing the sixth hypothesis (H06) coming from the main hypothesis, which states: "Information and communication system does not affect reducing fraudulent financial reporting".}

Table 7 shows the results of Multiple Linear Regression to measure the effect of information and communication system variable on reducing fraudulent financial reporting.

Table 7. Results of a simple linear regression analysis to test the sixth sub-hypothesis (HO6)

\begin{tabular}{l|c:c:c:c}
\hline \multicolumn{1}{c}{$\begin{array}{c}\text { Independent } \\
\text { variable }\end{array}$} & $\boldsymbol{\beta}$ & $\mathbf{T}$ & Sig. $\mathbf{t}$ & Decision \\
\hline $\begin{array}{l}\text { Information and } \\
\text { communication } \\
\text { system }\end{array}$ & -0.057 & -1.346 & 0.180 & Accept \\
\hline
\end{tabular}

The value of the coefficient $\beta$ shows the effect of the independent variable (information and communication system) on the dependent variable (fraudulent financial reporting), where the effect's value is -0.057 . The value of $T$ test shows the linear significance of the independent variable in the linear regression model, where the value of $T$ is 0.180 , which is greater than 0.05 . This means that there is no linear importance for information and communication system variable in reducing fraudulent financial reporting in commercial banks operating in Jordan.

As a result, the researchers accept zero study hypothesis and reject the alternative hypothesis, which states: "Information and communication system affects reducing fraudulent financial reporting".

\subsubsection{Testing the seventh hypothesis ( $\left.\mathrm{H}_{07}\right)$ coming from the main hypothesis, which states: "Monitoring does not affect reducing fraudulent financial reporting".}

Table 8 shows the results of Multiple Linear Regression to measure the effect of follow-up variable on reducing fraudulent financial reporting. 
Table 8. Results of a simple linear regression analysis to test the seventh sub-hypothesis (HO7)

\begin{tabular}{l|c:c:c:c}
\hline $\begin{array}{c}\text { Independent } \\
\text { variable }\end{array}$ & $\boldsymbol{\beta}$ & $\mathbf{T}$ & Sig. $\mathbf{t}$ & Decision \\
\hline Monitoring & 0.042 & 0.998 & 0.320 & Accept \\
\hline
\end{tabular}

The value of the coefficient $\beta$ shows the effect of the independent variable (monitoring) on the dependent variable (fraudulent financial reporting), where the effect's value is 0.042 . The value of $T$ test shows the linear significance of the independent variable in the linear regression model, where the value of $T$ is 0.320 , which is greater than 0.05 . This means that there is no linear importance for followup variable in reducing fraudulent financial reporting in commercial banks operating in Jordan.
The researchers explain the results of this hypothesis because the nature of the relationship between the follow-up variable and the variable of fraudulent financial reporting is indirect, so the follow-up variable is primarily related to follow-up by the internal audit department or supervision and inspection of the control procedures established by the executive management to identify any weaknesses in financial reporting, and take appropriate corrective measures.

As a result, the researchers accept zero study hypothesis and reject the alternative hypothesis, which states: "Monitoring affects reducing fraudulent financial reporting".

\section{CONCLUSION}

Applying COSO-ERM model enhances the effectiveness of internal control systems in reducing the risk of fraudulent financial reporting in commercial banks operating in Jordan, with the effect of $77.8 \%$ in the dependent variable (fraudulent financial reporting). The first variable in terms of the effect is the internal environment variable, followed by the events identification, followed by risk assessment and response variable, then control activities variable, followed by setting objectives variable. Monitoring and communication and information system variables have no effect on reducing the fraudulent financial reporting in commercial banks operating in Jordan.

The researchers believe that the reason for this impact is that the commercial banks operating in Jordan have efficient and effective internal control systems capable of achieving their regulatory objectives, including the fraudulent financial reporting reduction, which are based on the latest standards and recommendations of the internal control bodies such as the Committee of Sponsoring Organizations (COSO), International Federation of Accountants (IFAC), and the International Organization of Supreme Audit Institutions (INTOSAI). In addition, all banks operating in Jordan comply with the provisions of the Article (35/2007) "Instructions of Internal Control and Control Systems" issued by the Jordanian Central Bank, and with internal control standards issued by the Committee of Sponsoring Organizations.

\section{RECOMMENDATIONS}

Based on the study findings, the researchers make a number of recommendations that could enhance the effectiveness of the internal control system in reducing the risks of fraud.

1. The need to develop human resource policies and standards for the recruitment, training and promotion of human resources, based on attracting human resources that are practical, professional and ethical, as well as develop training programs specialized in fraud.

2. Banks need to focus on involving all employees at different administrative levels in the process of identifying events that may lead to fraud risks.

3. The need for a hot line of communication with the board of directors or its committees, such as the audit committee, to report cases of fraud or immoral behavior in secret. 
4. Banks as well as international organizations and bodies should periodically analyze and evaluate risks related to fraudulent risks arising from fraudulent financial reporting and fraud resulting from embezzlement or misuse of assets and develop effective measures to reduce them.

5. The need for continuous development and review for information and communication systems, including the accounting information system, which has an impact on reducing fraud risks.

6. The need for monitoring the evaluation process for internal control system by the responsible parties within a bank in accordance with the COSO-ERM model criteria to serve as a benchmark measure for banks to follow up and issue an annual report on the results of this evaluation.

\section{REFERENCES}

1. Abiola, I., \& Oyewole, A. T. (2013). Internal Control System on Fraud Detection: Nigeria Experience. Journal of Accounting and Finance, 13(5), 141-152. Retrieved from http://digitalcommons.www. na-businesspress.com/JAF/AbiolaI Web13_5_.pdf

2. Adebiyi, Ifeoluwa Mary (2017). Impact of Effective Internal Control in the Management of Mother and Child Hospital Akure, Ondo State. Journal of Finance and Accounting, 5(1), 61-73. Retrieved from http:// article.sciencepublishinggroup.com/ pdf/10.11648.j.jfa.20170501.16.pdf

3. Algire, Rasha Bashir (2013). Impact of Evaluation of Internal Control Components on Risk Assessment in Listed Companies in the Damascus Securities Market. Journal of the Whole, 15(III), 217.

4. Ani, Odunayo Boyepe (2014). Fraudulent Financial Reporting: The Nigerian Experience. Proceeding of The Clute Institute International Academic Conference San Antonio. USA: Texas.

5. Ayagre, P., Gyamerah, I., \& Nartey, J. (2014). The effectiveness of Internal Control Systems of banks: The case of Ghanaian banks. International Journal of Accounting and Financial Reporting, 4(2), 377-389. Retrieved from http://www.macrothink.org/ journal/index.php/ijafr/article/ viewFile/6432/_50

6. Committee of Sponsoring Organization of the Treadway Commission (2013). Internal Control - Integrated Framework. Retrieved from https://global. theiia.org/standards-guidance/ topics/Documents/Executive_ Summary.pdf
7. Ghosh, A. (2013). An Empirical Investigation into Enterprise Risk Management in India (Working paper series WPS No. 722). Indian Institute of Management Calcutta. Retrieved from https://www. iimcal.ac.in/sites/all/files/pdfs/ wps_722_0.pdf

8. International Federation of Accountants (IFAC) (2012, June). Evaluating and Improving Internal Control in Organizations. Retrieved from https://www.ifac.org/ publications-resources/evaluatingand-improving-internal-controlorganizations-0

9. International Federation of Accountants (IFAC) (2012). International Auditing and Assurance Standards Board, 1. Retrieved from https://www.kacr.cz/ file/1722/IAASB\%20HANDBOOK Vol\%201.pdf

10. Kehinde Adekunle Adetiloye, Felicia Omowunmi Olokoy, \& Joseph Niyan Taiw (2016). Fraud Prevention and Internal Control in the Nigerian Banking System. International Journal of Economics and Financial Issues, 6(3), 11721179. Retrieved from https://www. econjournals.com/index.php/ijefi/ article/viewFile/2035/pdf

11. Mohamed, Omar Ahmed, \& Dahdouh, Hussein Ahmed, (2013). Role of Audit Committees in Reducing Fraud in Syrian Shareholding Companies. Journal of Economic and Legal Sciences of Damascus University, 29(2).

12. Oguda N. J., Odhiambo, A., \& Byaruhanga, J. (2015). Effect of Internal Control on Fraud Detection and Prevention in District Treasuries of Kakamega
County. International Journal of Business and Management Invention, 4(1), 47-57. Retrieved from http:// www.ijbmi.org/papers/Vol(4)1/ F041047057.pdf

13. Rameli Mohd Nor Firdaus, MohdSanusi Zuraidah, Mat Isa Yusarina, \& Omar Normah (2013). Fraud Occurrences in Bank Branches: The Importance of Internal Cotrol and Risk Management. The 5th International Conference on Financial Criminology (ICFC)

"Global Trends in Financial Crimes in the New Economies". Retrieved from http://mak.trunojoyo.ac.id/ wp-content/uploads/2014/04/ P05_Internal-Control-FraudOccurence-in-Bank_Mohd-NorFirdaus-Rameli1.pdf

14. Reports Committee of Sponsoring Organizations of the Treadway Commission (2004). Enterprise Risk Management - Integrated Framework. Retrieved from https:// www.coso.org/Documents/COSOERM-Executive-Summary.pdf

15. Salehi, M., Shiri, M., \& Ehsanpour, F. (2013). Effectiveness of Internal Control in the Banking Sector: Evidence from Bank Mellat, Iran. The IUP Journal of Bank Management, 12(1), 23-34. Retrieved from https://papers.ssrn. $\mathrm{com} / \mathrm{sol} 3 /$ papers.cfm?abstract $\mathrm{id}=2255853$

16. Zauwiyah A., \& Mariati, N. (2008). The Control Environment, Employee Fraud and Counterproductive Workplace Behavior: An Empirical Analysis. Communications of the IBIMA, 3 , 145-155. Retrieved from http:// ibimapublishing.com/articles/ CIBIMA/2008/585197/585197.pdf 